\title{
Comment \\ Comment on: "A Bibliometric Analysis and Visualization of Medical Big Data Research" Sustainability 2018, 10, 166
}

\author{
Yuh-Shan Ho \\ Trend Research Centre, Asia University, No. 500, Lioufeng Road, Wufeng, Taichung County 41354, Taiwan; \\ ysho@asia.edu.tw
}

Received: 25 November 2018; Accepted: 18 December 2018; Published: 19 December 2018

Liao et al. recently published a paper in this journal entitled "A Bibliometric Analysis and Visualization of Medical Big Data Research" [1]. In "Section 2. Data and Methods", the authors specified the following: 'We took "medical big data" as topical retrieval and the time span was defined as "all years" (However, according to the returned results, we know that the first publication in MBD was appeared in 1991). The literature type was defined as "all types". In total, 988 documents met the selection criteria. Ten document types were found in these 988 publications.'

To check results in the original paper [1], we searched the Clarivate Analytics Web of Science, the online version of the Science Citation Index Expanded (SCI-EXPANDED), and the Social Science Citation Index (SSCI) on 2 November 2018. The databases were searched using the keywords "medical big data" in terms of topic (title, abstract, author keywords, and KeyWords Plus) within the publication years of 1900 to 2017. Only 18 documents could be found, including 15 articles, two meeting abstracts, and one editorial material but not "988 documents" as mentioned in the original paper [1]. The 15 medical big data-related articles were published by Al Hamid et al. [2], Azar and Hassanien [3], Chen et al. [4], Choi et al. [5], Chow-White et al. [6], Gao et al. [7], Hata and Nakajima [8], Iqbal et al. [9], Kim and Lee [10], Kong et al. [11], Wang et al. [12], Xia et al. [13], Yao et al. [14], Yuan et al. [15], and Zhao et al. [16]. In the same section, the authors noted: "However, according to the returned results, we know that the first publication in MBD was appeared in 1991". However, the article published in 1991, entitled "A Research-Oriented Medical Cost Accounting System" [17], is not related to "medical big data", as there is no mention of "big data" in the article.

The Science Citation Index Expanded (SCI-EXPANDED) and the Social Science Citation Index (SSCI) were originally designed for researchers to find published literature, but not intended for bibliometric study $[18,19]$. Thus, it is necessary to employ bibliometric analysis when using the Web of Science database for bibliometric study. Understanding of the database used and an appropriate data treatment are needed for bibliometric study. Liao et al. [1] used the wrong method and data to publish "A Bibliometric Analysis and Visualization of Medical Big Data Research" in Sustainability, and this may result in misleading readers of the journal.

\section{References}

1. Liao, H.C.; Tang, M.; Luo, L.; Li, C.Y.; Chiclana, F.; Zeng, X.J. A bibliometric analysis and visualization of medical big data research. Sustainability 2018, 10, 166. [CrossRef]

2. Al Hamid, H.A.; Rahman, S.M.M.; Hossain, M.S.; Almogren, A.; Alamri, A. A security model for preserving the privacy of medical big data in a healthcare cloud using a fog computing facility with pairing-based cryptography. IEEE Access 2017, 5, 22313-22328. [CrossRef]

3. Azar, A.T.; Hassanien, A.E. Dimensionality reduction of medical big data using neural-fuzzy classifier. Soft Comput. 2015, 19, 1115-1127. [CrossRef] 
4. Chen, M.; Hao, Y.X.; Hwang, K.; Wang, L.; Wang, L. Disease prediction by machine learning over big data from healthcare communities. IEEE Access 2017, 5, 8869-8879. [CrossRef]

5. Choi, J.K.; Jeon, K.H.; Won, Y.; Kim, J.J. Application of big data analysis with decision tree for the foot disorder. Clust. Comput. J. Netw. Softw. Tools Appl. 2015, 18, 1399-1404. [CrossRef]

6. Chow-White, P.; Ha, D.; Laskin, J. Knowledge, attitudes, and values among physicians working with clinical genomics: A survey of medical oncologists. Hum. Resour. Health 2017, 15, 42. [CrossRef] [PubMed]

7. Gao, L.L.; Pan, H.W.; Xie, X.Q.; Zhang, Z.Q.; Li, Q.; Han, Q.L. Graph modeling and mining methods for brain images. Multimed. Tools Appl. 2016, 75, 9333-9369. [CrossRef]

8. Hata, Y.; Nakajima, H. A survey of intelligent computing in medical and health care system. IEICE Trans. Inf. Syst. 2014, E97D, 2218-2225. [CrossRef]

9. Iqbal, U.; Hsu, C.K.; Nguyen, P.A.; Clinciu, D.L.; Lu, R.; Syed-Abdul, S.; Yang, H.C.; Wang, Y.C.; Huang, C.Y.; Huang, C.W.; et al. Cancer-disease associations: A visualization and animation through medical big data. Comput. Methods and Prog. Biomed. 2016, 127, 44-51. [CrossRef] [PubMed]

10. Kim, J.; Lee, W. Stochastic decision making for adaptive crowdsourcing in medical big-data platforms. IEEE Trans. Syst. Man Cybern.-Syst. 2015, 45, 1471-1476. [CrossRef]

11. Kong, X.Y.; Gong, S.; Su, L.J.; Cheng, X.Q.; Li, H.L.; You, T.T.; Kong, Y.G. Survivin overexpression is potentially associated with pituitary adenoma invasiveness. Oncotarget 2017, 8, 105637-105647. [CrossRef] [PubMed]

12. Wang, S.Z.; Jin, K.; Lu, H.T.; Cheng, C.M.; Ye, J.; Qian, D.H. Human visual system-based fundus image quality assessment of portable fundus camera photographs. IEEE Trans. Med. Imaging 2016, 35, 1046-1055. [CrossRef] [PubMed]

13. Xia, Q.; Sifah, E.B.; Asamoah, K.O.; Gao, J.B.; Du, X.J.; Guizani, M. MeDShare: Trust-less medical data sharing among cloud service providers via blockchain. IEEE Access 2017, 5, 14757-14767. [CrossRef]

14. Yao, Q.; Tian, Y.; Li, P.F.; Tian, L.L.; Qian, Y.M.; Li, J.S. Design and development of a medical big data processing system based on Hadoop. J. Med. Syst. 2015, 39, 23. [CrossRef] [PubMed]

15. Yuan, Y.W.; Chen, W.X.; Yan, L.M.; Huang, B.B.; Li, J.Y. A similarity-based disease diagnosis system for medical big data. J. Med. Imaging Health Informat. 2017, 7, 364-370. [CrossRef]

16. Zhao, W.Z.; Chen, J.J.; Perkins, R.; Wang, Y.P.; Liu, Z.C.; Hong, H.X.; Tong, W.D.; Zou, W. A novel procedure on next generation sequencing data analysis using text mining algorithm. BMC Bioinform. 2016, 17, 213.

17. Langer, R.D.; Wark, R.; Schneiderman, L.J.; Kaplan, R.M.; Anderson, J.P.; Chen, M. A research-oriented medical cost accounting system. Int. J. Bio-Med. Comput. 1991, 28, 161-167. [CrossRef]

18. Ho, Y.S. Comments on "Determining technology trends and forecasts of RFID by a historical review and bibliometric analysis from 1991 to 2005". Technovation 2009, 29, 725-727. [CrossRef]

19. Ho, Y.S. Comments on "Mapping the scientific research on non-point source pollution: A bibliometric analysis" by Yang et al. (2017). Environ. Sci. Pollut. Res. 2018, 25, 30737-30738. [CrossRef] [PubMed] 